\title{
PERCEPTION AND ACCEPTANCE OF ONLINE EDUCATION: DO ONLINE COURSES PASS THE MUSTER?
}

\author{
Deborah Kelly, University of San Diego,dkelly@sandiego.edu \\ Carl M. Rebman, Jr, University of San Diego, carlr@sandiego.edu \\ We would like to thank Nicole Zammit for her research assistance.
}

\begin{abstract}
This study seeks to evaluate the current state of online educational delivery and assess the perception of the these six issues - quality, rigor, engagement, retention, discussion component, and critical thinking - as well as acceptance of online education courses credits compared to the traditional face-to-face academic model. A survey instrument was distributed to over 500 faculty, university administrators, and students to solicit their feedback towards current practices, attitudes, and beliefs about online courses. This study found that most faculty, administrator, and students perceived online education to be inferior as compared to face-to-face delivery in six different areas. Furthermore, most faculty indicated an acceptance of online course credit for prerequisite traditional face-to-face undergraduate and graduate offerings. However, many faculty reported that online courses should not be replacement for face-toface in one's major field of study.
\end{abstract}

Keywords: Online Education, Distance Learning, E-Learning, Undergraduate Education

\section{INTRODUCTION}

Over the last twenty years, postsecondary institutions have experienced a rapid increase of alternative methods of instructional delivery. They have offered online education to address insufficient classroom space on campuses and the ability to appeal to new markets. Many working people can pursue a degree or update themselves in career areas with flexibility while not disrupting their work schedule or time with family. Because of the rise of online course offerings and student enrollment in these delivery methods, universities are experiencing an increase in requests to accept credit toward these traditional face-to-face course requirements.

Distance learning is rapidly becoming a popular option for delivery of course content. Text based correspondence courses, radio based delivery of lessons, and recent computer based technology have all contributed to the development of educational courses involving distance learning [17]. Some of the reasons for the popularity of online education can be attributed towards enrollment demands, economic necessity, need for family, time, and location flexibility, limited classroom space and emerging technologies. As such many states, institutions and organizations have been working on strategic plans to implement online education [10]. Kim and Bonk [10] further noted that with the increase of online course offerings it is not surprising that opinions are mixed about the benefits of online teaching and learning in higher education.

Perhaps one of the main reasons for the mixed opinions lies in the perceptions held by faculty, university administrators and employers. For example, O'Malley and McCraw [12] noted that until the 1980's "the primary educational delivery model for collegiate professorial staff was essentially the traditional lecture." As such, it is not surprising that many invested parties might have concerns about the transference of knowledge over new and perhaps untested technologies. Columbaro and Monaghan [9] completed a review of studies with respect to how employers perceive online coursework. They found lack of rigor and face-to-face interactions, as well as, academic dishonesty as reasons why employers tend to favor job candidates with a traditional degree rather than an online degree. O'Malley and McCraw [12] raised a question regarding "how well these new educational delivery approaches that move away from the basic face to face relationship between a professor and students impact student learning and student perceptions of learning."

Similar to the study for this paper, Tanner, Noser and Totaro [20] examined business faculty and university student perceptions about online learning. The two groups responded significantly different about flexibility, difficulty of tests, and interaction of students to students and students to professors. They found faculty was less favorable than students to online learning, but they mentioned a limitation of their study was to not include administrators' 


\section{Issues in Information Systems \\ Volume 15, Issue II, pp. 49-58, 2014}

perceptions. Our paper poses the question to faculty, administrators, and students about how the new online environment compares with the traditional face-to-face classroom.

Studies conducted on online education have also focused on feedback from the student learners who partake in the online education courses. These results are important to understand the strengths and weaknesses of the programs from an inside perspective. Poole [15] found the flexibility of online programs enabled them to learn at the pace that worked the best for them and made it easier to collaborate in groups. Petrides [14] surveyed seventy-six graduate students who participated in an online learning environment and found that a benefit of online courses was they had more time to reflect on the course material since they had to write down responses. Vonderwell [22] found a similar result that online courses cause students to write more carefully about their ideas. Yet, it was also found that student learners had a feeling of isolation due to a lack of sense of community and the long delay in response time from faculty.

The format of this study is as follows. First is a background of online education. A background of online education can be separated into three areas - demographics, the breakdown of institutions offering online courses, and learning outcomes. Next is a discussion of the research questions and methodology followed with the results of our survey. The last section discusses limitations and future research possibilities.

\section{ONLINE COURSES}

Today's post-secondary degrees offer students the options to engage in various delivery modes [9]. According to the 2005 Sloan Consortium report, Allen and Seaman [1] describe the following standard academic degree program configurations as:

- Traditional or Minor Web-Facilitated: No online technology used or 1 to 29 percent of course content is online through a course management system, such as Blackboard or WebCT, to support the primary use of the face-to-face format.

- Hybrid: 30 to 79 percent content covered online such as online discussions and readings; supplemented by occasional face-to-face classroom experience.

- Online: 80 percent plus of course content and interactions occur online (p. 4).

For purposes of this study online courses will be defined as those where most or all $(80+\%)$ of the content is delivered online and typically do not have face-to-face delivery. It may be interactive audio or videoconferencing, pre-recorded videos, webcasts, or computer-based systems delivered over the internet. Online degree programs, which are defined as entire degree programs taught online, will be addressed separately. All information is given for postsecondary education undergraduate level programs.

\section{Demographics}

From 2002 to 2011, the annual growth rate of those enrolled in at least one online class increased anywhere from 9.3 to 36.5 percent [3]. The National Center for Education Statistics reported in 2012 that $52.9 \%$ of Title IV institutions had no distance education courses, $0.4 \%$ had exclusively distance education, and $46.7 \%$ had at least some distance education possibility. Public institutions were the first to offer online courses and have continued to be the front runner of course offerings. At the University of Central Florida, $80 \%$ of the students who enroll for online classes are from the millennial generation (born after 1980) [11]. Yet, the U.S. average is that students are generally older, have a dependent and/or spouse, or have full-time employment $[8,16]$. Students with disabilities $(26 \%)$ enroll in online classes or degree programs more often than students with no disabilities (20\%) [196]. A study published in 2012 confirmed the percentage of students older than 30 was a majority (60\%), and of all online students, two-thirds attend not-for-profit institutions [4].

\section{Breakdown of institutions offering online courses}

When considering online courses it is helpful to have a historical perspective of the number of offerings from institutions over time. For example, the percentage of 2- and 4- year degree granting institutions offering distance education courses rose from 33 to 44 percent between 1994 and 1997 [21]. For the school year 2000 to 2001, 56 percent of all 2-year and 4-year Title IV-eligible, degree-granting institutions offered distance education courses and 


\section{Issues in Information Systems \\ Volume 15, Issue II, pp. 49-58, 2014}

another 12 percent of all institutions indicated that they planned to start offering distance education courses in the next 3 years [19]. In 2012, the percentage of institutions offering online courses and full programs were: 72.9 percent of private for-profit colleges, 48.4 percent of private non-profit, and 70.6 percent of public colleges.

\section{Learning outcomes}

The institutions not offering online learning perceive this type of learning to be inferior to face-to-face learning more often than those who are offering courses or degree programs. Figure 1 illustrates the survey results when academic leaders were asked about their perception of the comparison between the two learning styles [2]. The 2013 report by Allen and Seaman [5] indicates that between 2003 and 2012 the perception of learning outcomes has improved. In $2003,42.8 \%$ answered that online was inferior or somewhat inferior compared to face-to-face. Yet in 2012, only about half as many or $23 \%$ answered that online was inferior.

A study completed in 2010 by the Legislative Analyst's Office in California found that the online method of learning helped students learn more than a comparable face-to-face class due to extra learning time and increased faculty interaction [13]. However, it concluded that prepared students have better results than underprepared students. Other studies have pointed to the self-discipline required for an online class is what enables success.

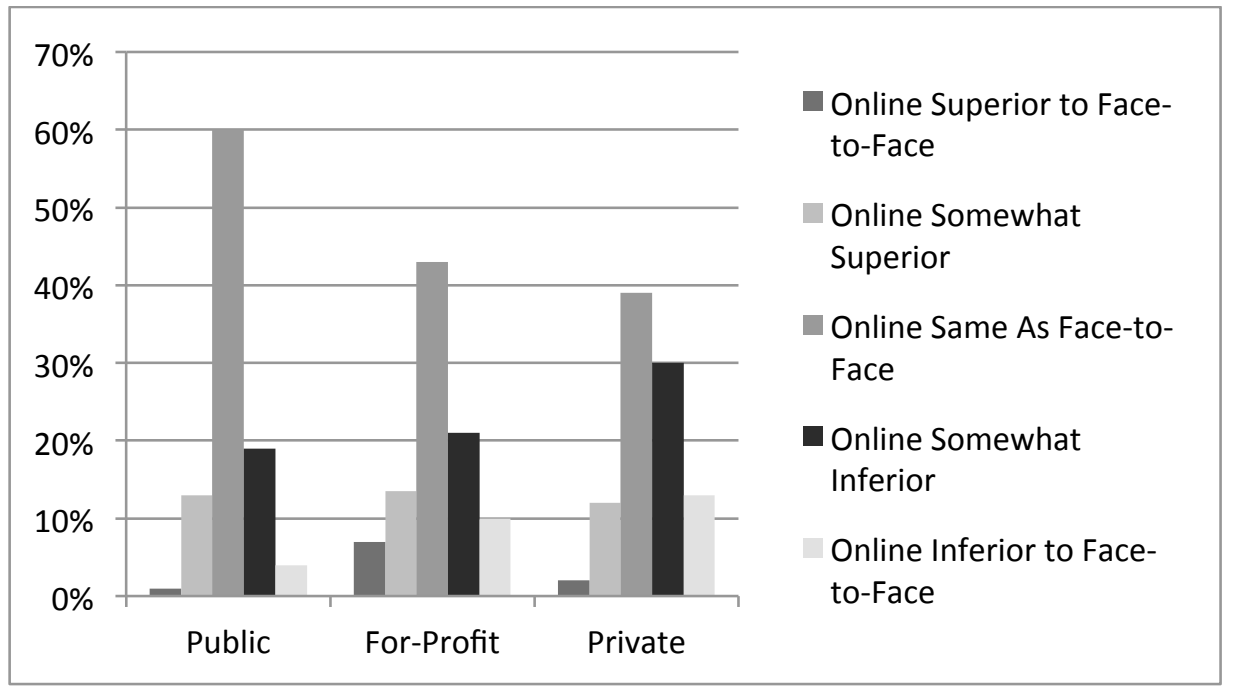

Figure 1. The perception of academic leaders about learning outcomes in online courses compared to face-to-face by type of institution, Fall 2010. Source: Babson Survey Research Group, 2010 [2].

\section{RESEARCH QUESTIONS}

This study seeks to examine several issues related to the acceptance of undergraduate online courses as an alternative to traditional face-to-face delivery. Specifically, the issues addressed in this research compare online and face-to-face with respect to: 1) online course quality, 2) course / assignment rigor, 3) engagement of students, 4) retention of course content, 5) discussion depth, 6) enhancement of critical thinking, 7) online course credit acceptance by faculty for prerequisite courses, 8) quality of learning of for-profit college online courses compared to 4-year college online course quality, 9) quality of learning of for-profit college online courses compared to 2-year college online courses, and 10) quality of learning of a 4-year college online course as compared to 2-year college online course quality.

There are a multitude of aspects that contribute to student learning whether the course is delivered online or face-toface. This study probed six issues in which faculty members, university administrators and students could compare the two delivery styles. The survey questions allowed these groups to give their feedback on a scale from online is inferior (1) to online is superior (10) for each issue. Statistically, we expected there to be no difference between the means of each group about each issue. 


\section{Issues in Information Systems \\ Volume 15, Issue II, pp. 49-58, 2014}

The first aspect questioned the perception of quality of online education as compared to face-to-face delivery. The expectation was that all three groups would perceive online to be of a lower quality, and this would be consistent with the research findings of the Allen and Seaman [2]. In addition, the expectation that the other five issues would be congruous with this finding that all three groups would perceive online to be less rigorous, less engaging for the student, and enhance critical thinking less than face-to-face delivery. Retention of course content and the discussion experience were also expected to be inferior with online.

The next area of study was whether a faculty member would accept credit or not for undergraduate or graduate online courses that were a prerequisite for their class or prefer the class was completed in a face-to-face environment. The expectation was that faculty would accept online courses less in concurrence with the previous issues that faculty would perceive online courses as inferior.

The last area of study was having faculty, administrators and students compare the quality of learning between two different college institution categories on a 10-point Likert scale. The groups compared for-profit college online courses to a 4-year college online course, then for-profit to 2-year colleges and 4-year to 2-year colleges. The intent was to seek how these groups perceived the institutions individually rather than as a group. The expectation was that for-profit online college courses would be ranked as the lowest quality of learning with 4-year colleges to have a higher quality level and 2-year colleges in the middle. The research questions and each related set of hypotheses are stated below.

1. What impact does online class instruction have compared to face-to-face delivery with respect to course quality, rigor, engagement, course retention, discussions, and critical thinking?

H1. There is no difference between the mean results of faculty members, university administrators, and students perceptions of the quality, rigor, engagement, course retention, discussions, and critical thinking of online classes compared to traditional face-to-face delivery.

2. If given a choice, would faculty members accept credit for an online course that was a prerequisite for their class as compared to a face-to-face course?

H2a: Faculty members would accept undergraduate online courses less often than traditional face-to-face for a prerequisite course.

H2b: Faculty members would accept graduate online courses less often than traditional face-to-face for a prerequisite course.

3. How does the quality of for-profit, 4-year, or 2-year colleges compare with each of the other two college online courses?

H3a. Faculty members, university administrators, and students perceive online course quality of learning offered by a for-profit college to be less than a 4-year college online course.

H3b. Faculty members, university administrators, and students perceive online course quality of learning offered by a for-profit college to be less than a 2-year college online course.

H3c. Faculty members, university administrators, and students perceive online course quality of learning offered by a 4-year college to be more than a 2-year college online course.

\section{RESEARCH STUDY METHODOLOGY}

A survey was conducted of individuals believed to have relevant experience with and insights into the factors affecting the present and future state of online education. The questionnaire consisted of 22 items and was distributed electronically nationwide through listservs and word of mouth. Out of the 524 fully completed and useable responses, $41 \%$ were male and $59 \%$ were female. The geographic distribution included $75.6 \%$ from 


\section{Issues in Information Systems \\ Volume 15, Issue II, pp. 49-58, 2014}

California, $21.7 \%$ from other states, and 2.7\% from international locations. In addition, $23 \%$ (120) were faculty, $10 \%$ (54) were administration, and 67\% (350) were students. Cronbach alpha tests of reliability on the questionnaire produced a result of 0.828 .

Given the large representation from California, statistical tests were done to compare the means from other locations versus California with respect to the six issues of online learning in hypothesis one and college quality in hypothesis three. There was a significant difference between the means between the Southern States $(n=12)$ and California for rigor $(\mathrm{p}=.019)$, however no other location had a statistically significant mean difference than California. For different college quality of online learning for hypothesis three, there was no statistically significant difference between the means of California and other locations.

\section{RESULTS AND DISCUSSION}

\section{Hypothesis 1}

This hypothesis compared online classes with face-to-face in terms of quality, rigor, engagement, retention of concepts, discussions, and critical thinking as perceived by administrators, faculty, and students. The expectation was that online would be perceived as inferior for all issues. In three circumstances, students did not have the same perception as the administration and faculty. Instead the students perceived the online course quality, engagement, and discussions to be statistically more inferior than the administrators or faculty perceived these issues.

Table 1 provides the descriptive statistics of the six factors of online education studied and Table 2 provides the mean scores per individual groups. The Likert scale was from 1 (online is inferior) to 10 (online is superior) with 5 meaning online and face-to-face are the same. All of the mean values are less than 5 indicating that all three groups for all six factors perceive online courses to be inferior to face-to-face courses. Table 2 results show that for every factor the administrators and faculty perceive online courses to be less inferior as compared to students.

Table 1 Descriptive Statistics for All Categories - Administration, Faculty, and Students

\begin{tabular}{lcccccc}
\hline & Quality & Rigor & Engagement & Retention & Discussions & $\begin{array}{c}\text { Critical } \\
\text { Thinking }\end{array}$ \\
\hline & & & & & & \\
Mean & 2.91 & 3.49 & 3.06 & 3.63 & 3.44 & 3.60 \\
Standard Deviation & 1.66 & 1.88 & 1.85 & 1.78 & 2.23 & 1.91 \\
$\mathrm{n}$ & 524 & 524 & 523 & 522 & 521 & 518 \\
\hline
\end{tabular}

Table 2 Mean Scores of Each Question Per Group (Scale of 1 to 10, where $1=$ Online is inferior and $10=$ Online is superior to face-to-face)

\begin{tabular}{lcccccc}
\hline & Quality & Rigor & Engagement & Retention & Discussions & $\begin{array}{c}\text { Critical } \\
\text { Thinking }\end{array}$ \\
\hline Administration & 3.41 & 3.87 & 3.41 & 3.87 & 3.87 & 3.87 \\
Faculty & 3.08 & 3.61 & 3.43 & 3.84 & 4.01 & 3.70 \\
Students & 2.77 & 3.39 & 2.87 & 3.51 & 3.18 & 3.52 \\
All Groups & 2.91 & 3.49 & 3.06 & 3.63 & 3.44 & 3.60
\end{tabular}

To test for the difference in the means between groups, SPSS was used to complete ANOVA and Mean Difference tests, checking first for the homogeneity of variances with a Levene Statistic for significance (Table 3). The discussion variable did have a significant Levene Statistic (3.336, $\mathrm{p}<.05)$, yet all other variables were not significant indicating equal variances. 
Issues in Information Systems

Volume 15, Issue II, pp. 49-58, 2014

\begin{tabular}{lcc|lcc}
\hline \multicolumn{1}{c}{ Variable } & $\begin{array}{c}\text { Levene } \\
\text { Statistic }\end{array}$ & Sig. & \multicolumn{1}{c}{ Variable } & $\begin{array}{c}\text { Levene } \\
\text { Statistic }\end{array}$ & Sig. \\
\hline Quality & 0.309 & 0.734 & Retention & 1.197 & 0.303 \\
Rigor & 0.245 & 0.783 & Discussions & 3.336 & $0.036^{*}$ \\
Engagement & 0.113 & 0.894 & Critical Thinking & 0.060 & 0.942
\end{tabular}

$* \mathrm{p}<.05$

Games-Howell was used for the discussions variable since equal variances cannot be assumed. In addition, with different sample sizes Tukey's HSD test was run. Table 4 shows the results of the difference between the means. Except for three groups below, the difference between the means was equal to zero ( $>$ >05). As far as quality, engagement, and discussions for online courses, students perceive these areas much more inferior compared to faceto-face classes than administrators or faculty. Therefore for Hypothesis 1, there was a difference between the mean results of these groups and the hypothesis would be rejected for the aspects above.

- Quality: Administration / Student - The difference between the two means was 0.64 and $\mathrm{p}=0.022$.

- Engagement: Faculty / Student - The difference between the two means was 0.56 and $p=0.012$.

- Discussions: Faculty / Student - The difference between the two means was 0.82 and $p=0.003$.

Table 4 Tests for the difference in the means between the groups

\begin{tabular}{|c|c|c|c|}
\hline Dependent Variable & Variable 1 & Variable 2 & Sig. \\
\hline $\begin{array}{l}\text { Quality } \\
\text { (Tukey's HSD) }\end{array}$ & $\begin{array}{l}\text { Faculty } \\
\text { Faculty } \\
\text { Admin }\end{array}$ & $\begin{array}{l}\text { Admin } \\
\text { Student } \\
\text { Student } \\
\end{array}$ & $\begin{array}{r}0.457 \\
0.166 \\
0.022 * \\
\end{array}$ \\
\hline $\begin{array}{l}\text { Rigor } \\
\text { (Tukey's HSD) }\end{array}$ & $\begin{array}{l}\text { Faculty } \\
\text { Faculty } \\
\text { Admin }\end{array}$ & $\begin{array}{l}\text { Admin } \\
\text { Student } \\
\text { Student }\end{array}$ & $\begin{array}{l}0.665 \\
0.519 \\
0.184\end{array}$ \\
\hline $\begin{array}{l}\text { Engagement } \\
\text { (Tukey’s HSD) }\end{array}$ & $\begin{array}{l}\text { Faculty } \\
\text { Faculty } \\
\text { Admin }\end{array}$ & $\begin{array}{l}\text { Admin } \\
\text { Student } \\
\text { Student }\end{array}$ & $\begin{array}{r}0.996 \\
0.012 * \\
0.117 \\
\end{array}$ \\
\hline $\begin{array}{l}\text { Retention } \\
\text { (Tukey's HSD) }\end{array}$ & $\begin{array}{l}\text { Faculty } \\
\text { Faculty } \\
\text { Admin }\end{array}$ & $\begin{array}{l}\text { Admin } \\
\text { Student } \\
\text { Student } \\
\end{array}$ & $\begin{array}{l}0.994 \\
0.192 \\
0.354 \\
\end{array}$ \\
\hline $\begin{array}{l}\text { Discussions } \\
\text { (Games-Howell) }\end{array}$ & $\begin{array}{l}\text { Faculty } \\
\text { Faculty } \\
\text { Admin } \\
\end{array}$ & $\begin{array}{l}\text { Admin } \\
\text { Student } \\
\text { Student } \\
\end{array}$ & $\begin{array}{r}0.939 \\
0.003 * * \\
0.147 \\
\end{array}$ \\
\hline $\begin{array}{l}\text { Critical Thinking } \\
\text { (Tukey's HSD) }\end{array}$ & $\begin{array}{l}\text { Faculty } \\
\text { Faculty } \\
\text { Admin }\end{array}$ & $\begin{array}{l}\text { Admin } \\
\text { Student } \\
\text { Student }\end{array}$ & $\begin{array}{l}0.852 \\
0.656 \\
0.427\end{array}$ \\
\hline
\end{tabular}

$* \mathrm{p}<.05, * * \mathrm{p}<.01$

To elaborate on some of these quantitative findings, the survey asked respondents about their general opinion of online courses and gave them room to provide qualitative support for their answers.

Quality - The quality of online classes is perceived to be quite varied with respect to the institution and professor teaching the class. Fifteen percent of the comments mentioned that quality is somewhat dependent on the professors and many are not well trained to teach online. Nine percent said that online classes teach and require self-discipline, therefore you get out of it what you put into it. 


\section{Issues in Information Systems \\ Volume 15, Issue II, pp. 49-58, 2014}

Rigor - Reasons given for why rigor is less for an online as compared to face-to-face is that online courses are easy to float through. Multiple respondents commented that you can multi-task the coursework while watching TV, talking on the phone, or use more than one computer to look up answers while taking a test. Lack of accountability and online courses are easier were mentioned in $16.3 \%$ of the comments.

Engagement - Engagement in computer mediated discussions can be hampered by individuals who utilize flaming or irrelevant comments as well as by individuals who can type faster than others and thus dominate the discussion. Thirty-two percent of the comments mentioned various reasons to support online classes lacking engagement and little or no interaction between professor and students. Consistent with Aslanian and Clinefelter study of 1500 students [4], respondents said students lose out on the interpersonal relationships and interactions that take place in the traditional face-to-face environment. One person said, "There is a disconnect in online courses between questions and responses; and I believe having to speak in class to ask or answer questions builds confidence, interpersonal skills, public speaking skills and critical thinking." The second lowest mean score of the six issues was with engagement.

Song [18] conducted a study which revealed the main challenges of student's online learning experiences. The prominent challenges included a lack of sense of community, difficulty understanding instructional goals, and technical problems. These factors associated with online courses affected the satisfaction of the students. The participants who reported lower satisfaction with the online course compared to a traditional classroom agreed that the design of the course (89\%), motivation of the learner (82\%), and comfort with online technology $(82 \%)$ were essential elements for an online course to be successful.

Retention - Retention was one area that online courses were reported to being closer to the same as traditional faceto face courses (average mean was 3.63), yet was still inferior. Some of the rationale that support this higher mean over other areas might be attributed to the fact that online courses have better flexibility which allows for students to be able to determine the best time for them to learn. Online class flexibility for families, locations underserved by higher education institutions, full time workers, and commuters was mentioned in $15 \%$ of the comments. The comments about flexibility are consistent with Allen and Seaman [3] who found some of the primary reasons for enrolling in online classes are due to the exact ones we received. In addition, online courses can be viewed and reviewed as to allow for multiple exposures to the same message in the same format. The traditional face-to-face only offers a one-time live experience unless recorded which is less often than not. Computers remove the non-verbal element that is necessary for in depth group discussions. There are also challenges with online group computer mediated discussions as comments can get misconstrued when read as opposed to hearing in real time.

Discussions - There were frequent comments that online courses help to get all the students talking and involved in discussions rather than just a few in the traditional classroom. This perception was supported by the fact that the computer can track and professors can quantify the number of comments posted. There is also the belief that online communication is better suited for those individuals who are introverted and shy to speak up in public. Due to the immediacy and ease of entry, more comments and ideas can be generated. However, as noted in the engagement issue sometimes the quality of the discussions can be diminished. Discussions can often go off topic and thus lose participant interest.

Critical Thinking - Critical thinking itself is challenging to measure whether it be online or in the traditional faceto-face. Overall respondents felt that there was less critical thinking in an online course than a traditional face-toface offering. This could be attributed to the impersonal nature of the computer-mediated nature of online courses. For example one participant responded with "There's more to communication and learning than responding via a computer." Another rationale for the lower critical thinking component could stem from the self-directed requirement of online education. Respondents felt that the nature of being required to physically come to class and react in person with professors and students fosters critical thinking because on the real time demand of effort. Lastly, many respondents felt that online courses were focused more on actual assignment deliverables as opposed to the educational learning process that occurs in a traditional academic setting. 


\section{Issues in Information Systems \\ Volume 15, Issue II, pp. 49-58, 2014}

Lastly, it is difficult to monitor and authenticate the true identity of the student registered for an online class. Who answered the test questions, wrote and/or posted the discussion answer, or passed and received credit for the class? Cheating was mentioned by many respondents as a major area of concern for the future of online education.

\section{Hypothesis 2}

Despite the reported perception of inferiority for online classes, $61 \%$ of faculty did agree they would accept an undergraduate online course as a prerequisite requirement for a course they would be teaching. This acceptance was stronger for undergraduate courses than a graduate course (52\%). Statistically, there was no difference between the proportions. Respondents were more specific in describing the types of courses that they would consider accepting for credit, i.e., reading and writing, memorization, and general education or lower division courses. They were quite clear that online courses should not be accepted for classes in one's major course of study. The results indicate that we should reject our hypotheses that faculty would accept online less than face-to-face prerequisite courses for undergraduate or graduate programs.

\section{Hypothesis 3}

This hypothesis compares the quality of online class learning at for-profit, 2-year, and 4-year colleges. The Likert scale was from 1 (inferior) to 10 (superior) with 5 meaning the two types of colleges have similar online class learning quality. Table 5 shows respondents from all three categories reported that on average the quality of learning of for-profit online courses were lower than (mean is less than 5.0) those offered by both traditional 2 and 4-year colleges. They also reported that on average online class quality of learning offered by 4-year colleges were of similar quality to 2 -year colleges. Therefore, hypotheses $3 \mathrm{a}$ and $3 \mathrm{~b}$ were not rejected, yet $3 \mathrm{c}$ would be rejected.

To test if there was a significant difference between the means, first the Levene Statistic was calculated to determine if the variances could be assumed equal and then based on those results the ANOVA results could be calculated. Table 6 indicates the variances were not equal for the 4-year college quality versus the 2-year colleges, and therefore the Games Howell was used while Tukey's HSD was used to determine the significance of the mean difference between for-profit colleges versus 2-year and 4-year colleges.

There was a difference in the means between the faculty and student categories with the perception of online class quality of learning comparing the for-profit and 2-year colleges. Students perceived the for-profit colleges had a slightly higher quality of learning as compared to the 2-year colleges, yet it is still in the inferior range. There was no difference in the means between any other group in their perception of online learning at the different institutions.

Table 5 Descriptive Statistics for All Categories (Administration, Faculty, and Students) Comparing Online Class Quality of Learning from One Type of Institution to Another

\begin{tabular}{lccccccc} 
& \multicolumn{3}{c}{ For-Profit / 4-Year } & \multicolumn{2}{c}{ For-Profit / 2-Year } & \multicolumn{2}{c}{ 4-Year / 2-Year } \\
\hline Category & $n$ & Mean & $\begin{array}{c}\text { Standard } \\
\text { Deviation }\end{array}$ & Mean & $\begin{array}{c}\text { Standard } \\
\text { Deviation }\end{array}$ & Mean & $\begin{array}{c}\text { Standard } \\
\text { Deviation }\end{array}$ \\
\hline Administration & 56 & 3.14 & 2.14 & 3.48 & 2.23 & 5.32 & 2.67 \\
Faculty & 126 & 2.90 & 1.85 & 3.52 & 2.07 & 5.32 & 2.22 \\
Students & 353 & 3.38 & 2.11 & 4.08 & 2.17 & 5.72 & 2.71 \\
All Groups & 535 & 3.24 & 2.06 & 3.88 & 2.16 & 5.58 & 2.60
\end{tabular}

Table 6 Test of Homogeneity of Variances for Each Type of Institution

\begin{tabular}{lcc}
\hline \multicolumn{1}{c}{ Variable } & Levene Statistic & Sig. \\
\hline For-Profit compared with 4 4-Year Colleges & 0.831 & 0.436 \\
For-Profit compared with 2 2-Year Colleges & 0.487 & 0.615 \\
4-Year compared with 2-Year Colleges & 6.069 & $.002 * *$ \\
$* * \mathrm{p}<.01$ & &
\end{tabular}


Table 7 ANOVA Tests for the difference in the means between the groups

\begin{tabular}{|l|c|c|r|}
\hline \multicolumn{1}{|c|}{ Dependent Variable } & Variable 1 & Variable 2 & \multicolumn{1}{c|}{ Sig. } \\
\hline For-Profit Compared with 4-Year Colleges & Faculty & Admin & 0.751 \\
(Tukey's HSD) & Faculty & Student & 0.068 \\
& Admin & Student & 0.702 \\
\hline For-Profit Compared with 2-Year Colleges & Faculty & Admin & 0.995 \\
(Tukey's HSD) & Faculty & Student & $0.032^{*}$ \\
& Admin & Student & 0.131 \\
\hline 4-Year Colleges Compared with 2-Year Colleges & Faculty & Admin & 1.000 \\
(Games-Howell) & Faculty & Student & 0.229 \\
& Admin & Student & 0.558 \\
\hline
\end{tabular}

$* \mathrm{p}<.05$

\section{LIMITATIONS AND FUTURE RESEARCH}

The results of this study indicate that online courses are inferior to traditional face-to-face courses particularly in the areas of quality, rigor, engagement, retention, discussion, and critical thinking. Furthermore, the results also indicate that more faculty are willing to accept online courses as credit for prerequisite courses and there is no difference between undergraduate and graduate level courses. Lastly, the results reinforce that the type of institution that offers the online course has an impact on perception of the quality of the online course offering. For-profit institutions have a perception of offering lower quality courses while 2 and 4-year college online courses are perceived as having higher quality.

However, there were some limitations. First, this study did not include the perspective of employers which arguably play a considerable role in the acceptance of online education. Secondly, the study had a large variance in the number of respondents in each category as more students responded to the survey than faculty. Statistically this is not an issue especially if you compare the percentage of students versus the percentage of faculty in the population at a university or in the United States. Lastly, the survey did not include any references to the MOOC (Massive Open Online Courses) type of online course offerings. Future research can help to provide more information if the areas researched in this study are equally important to satisfy employer educational training needs. Furthermore, future research can be helpful in identifying how to improve the deficiencies in the current perception of online education quality, rigor, engagement, retention, discussions, and critical thinking.

\section{CONCLUSIONS}

According to a study by Babson College [3], many of our results are somewhat consistent with their study of online education. Allen and Seaman [3] found that as online courses and programs have grown, chief academic officers believe only 30.2 percent of their faculty accepts the value and legitimacy of online education. This rate has actually decreased compared to their previous study in 2004. Twenty-five percent of academic leaders believe online course learning outcomes are inferior as compared to face-to-face (p. 24). These results indicate online is inferior but not as inferior as our study results.

There are different predictions about the growth potential and future of online learning. Canadian and European attempts at online colleges have mostly met with failure [11]. Some predictions are that future growth will not come from new programs or institutions but instead from the increase in existing program offerings. Public institutions are feeling some pressure from for-profit schools to continue to offer more courses and degree programs online, however for-profit growth was stunted in 2011 by negative reports, accreditation issues, and inability of students to transfer to public or private institutions. A variety of political and economic factors could change demand for traditional and online education in the future. This study sought to provide some insight as to the important variables that are related to the acceptance of online education, pursued the research limitation of Tanner, Noser, and Totaro [20] that did not include administrators' perceptions along with faculty and students for comparison, gave insight into faculty acceptance of online undergraduate and graduate courses, and compared the perception of online courses at for-profit colleges versus two-year versus four-year colleges. 


\section{REFERENCES}

1. Allen, I.E. \& Seaman, J. (2005). Growing by degrees: Online education in the United States, 2005. Sloan Consortium, 1-24.

2. Allen, I.E. \& Seaman, J. (2010). Class difference\$: Online education in the United States. Babson Survey Research Group.

3. Allen, I.E. \& Seaman, J. (2013). Changing Course: Ten Years of Tracking Online Education in the U.S.. Babson Survey Research Group.

4. Aslanian, C.B. \& Clinefelter, D.L. (2012). Online college students 2012: Comprehensive data on demands and preferences. Louisville, KY: The Learning House, Inc.

5. Aslanian, C. B., \& Clinefelter, D. L. (2013). Online college students 2013: Comprehensive data on demands and preferences. Louisville, KY: The Learning House, Inc.

6. Beqiri, M.S., Chase, N.M. \& Bishka, A. (2010). Online course deliver: An empirical investigation of actors affecting student satisfaction, Journal of Education for Business, 85, 95-100.

7. Bolkan, J. (2013, June). Students Taking online Courses Jumps $96 \%$ over 5 years. Retrieved from http://campustechnology.com/articles/2013/06/24/report-students-taking-online-courses-jumps-96-percentover-5-years.aspx? $=$ CTCC .

8. Booker, Q.E. \& Rebman, C.M. (2005). E-Student retention: Factors affecting customer loyalty for online program success, Issues in Information Systems, 6(1), 183-189.

9. Columbaro, N.L. \& Monaghan, C.H. (2009) Employer perception of online degrees: A literature review. Online Journal of Distance Learning Administration, 12(1).

10. Kim, K.J., \& Bonk, C.J. (2006) The future of online teaching and learning in higher education: The survey says. EDCUASE Quarterly, 29(4).

11. Mayadas, A.F., Bourne, J. \& Bacsich, P. (2009, January). Online education today, Science. 323(5910), 8589.

12. O'Malley, J. and McCraw, H. (1999) Student's perception of distance learning, online learning, and the traditional classroom. Online Journal of Distance Learning Administration, 2(4). Retrieved from http://www.westga.edu/ distance/omalley24.html.

13. Perez, E. (2010, October 26). Report: Colleges should offer more online classes, Higher Education. Retrieved October 2011 from http://californiawatch.org/dailyreport/report-colleges-should-offer-moreonline-classes-6097.

14. Petrides, L.A. (2002). Web-based technologies for distributed (or distance) learning: creating learningcentered educational experiences in the higher education classroom. International Journal of Instructional Media, 29(1), 69-77.

15. Poole, D.M. (2000) Student participation in a discussion-oriented online course: A case study. Journal of Research on Computing in Education, 33(2), 162-177.

16. Radford, A.W. (2011, October). Learning at a Distance: Undergraduate enrollment in distance education courses and degree programs. National Center for Education Statistics.

17. Rodriques, S. (1999) An evaluation of an online master course in science teacher education. Journal of Education for Teaching. 25(3), 263-270.

18. Song, L., Singleton, E. S., Hill, J. R., \& Koh, M. H. (2004). Improving online learning: Student perceptions of useful and challenging characteristics. The internet and higher education, 7(1), 59-70.

19. Tabs, E.D., Waits, T., Lewis, \& Greene, B. (2003). Distance education at post-secondary institutions 20002001 (NCES 2003-017). U.S. Department of Education, National Center for Education Statistics.

20. Tanner, J.R., Noser, T.C., \& Totaro, M.W. (2009). Business Faculty and Undergraduate Students' Perceptions of Online Learning: A Comparative Study. Journal of Information Systems Education, 20(1), 29-38.

21. Thomas, D. (1999) http://www2.ed.gov/PressReleases/12-1999/distance.html, Retrieved October 2011.

22. Vonderwell, S. (2003). An examination of asynchronous communication experiences and perspectives of students in an online course: A case study. Internet and Higher Education, 6, 77-90. 